\title{
Provenance and weathering index of the Upper Cretaceous São Carlos Formation and its tectonic significance in the eastern Bauru Basin, SE Brazil Proveniência e Intemperismo da Formação São Carlos, Cretáceo Superior, e significado tectônico na borda leste da Bacia Bauru, SE Brasil
}

\author{
Lara Ferreira Neves ${ }^{1}$ (D), Alessandro Batezelli ${ }^{2}$ (D) \\ 'Universidade Federal do Paraná - UFPR, Department of Geology, Av. Cel. Francisco H. dos Santos, 210, \\ Jardim das Américas, ZIPCODE 81531-980, Curitiba, PR, BR (larafneves@hotmail.com) \\ 2Universidade Estadual de Campinas - UNICAMP, Department of Geology and Natural Resources, Campinas, SP, BR \\ (abatezelli@ige.unicamp.br) \\ Received on March 8, 2018; accepted on May 24, 2019
}

\begin{abstract}
Geochemistry of major and trace elements has been used as an important tool for the study of provenance and tectonic and climatic evolution of sedimentary basins. The São Carlos Formation is an Upper Cretaceous unit that lies on the eastern border of the Bauru Basin. Despite the paleontological and paleodepositional studies performed in this unit in the last years, little is known about the correspondence between tectonic and climatic conditions acting during the first stages of sedimentation. The hypothesis of this paper is to evaluate São Carlos and Araçatuba formations and understand the evolution of the eastern border of the basin. Thus, were conducted geochemical studies using X-ray fluorescence on sandstones, siltstones, and shales from the São Carlos Formation. According to the chemical weathering index, which presented values ranging from 57.12 to $71.58 \%$, the oxides of major elements indicate that moderate weathering processes affected the source area, possibly associated with the arid-semiarid climate. Alkaline rocks, granites, gneisses, and metasediments were the main lithotypes of the source area. Ternary diagrams show that the tectonic environment was equivalent to the passive continental margin, coinciding with the Serra do Mar and, secondarily, Alto Paranaíba Uplift regions. Based on major and trace elements, their ratios, and published data on the basin, was elaborated a paleogeographic model of the eastern border of the Bauru Basin, concluding that the source area of the sediments was constituted by intermediate and felsic rocks, sometimes recycled by sedimentary processes.
\end{abstract}

Keywords: Bauru Basin; Geochemistry; Provenance; Weathering.

\section{Resumo}

A geoquímica dos elementos maiores e traço tem sido usada como importante ferramenta para o estudo da proveniência, evolução tectônica e climática das bacias sedimentares. A Formação de São Carlos é uma unidade do Cretáceo Superior que ocorre na borda leste da Bacia Bauru. Apesar dos estudos paleontológicos e paleodeposicionais realizados nesta unidade nos últimos anos, pouco se sabe sobre as condições tectônicas e climáticas que atuam nos primeiros estágios da sedimentação, bem como, sua relação estratigráfica com outras unidades da bacia. A hipótese deste trabalho consiste em avaliar se as formações São Carlos e Araçatuba possuem correspondência e compreender a evolução da margem leste da bacia. Dessa forma, realizaram-se estudos geoquímicos utilizando Fluorescência de Raios-X em arenitos, siltitos e folhelhos da Formação São Carlos. Através do uso do índice de intemperismo químico, os óxidos dos elementos maiores indicam que, com valores entre 57,12 e 71,58\%, os processos de intemperismo moderados, possivelmente associados ao clima árido-semiárido, afetaram a área de origem. Rochas alcalinas, granitos, gnaisses e metassedimentos foram os principais litotipos da área fonte. Os diagramas ternários indicam que o ambiente tectônico era equivalente à margem continental passiva, coincidindo com as regiões da Serra do Mar e, em segundo lugar, Soerguimento Alto Paranaíba. Com base nos elementos maiores e traços, suas razões, e dados já publicados da bacia, foi elaborado um modelo paleogeográfico da borda leste da Bacia Bauru, concluindo-se que a área de origem dos sedimentos foi constituída por rochas intermediárias e félsicas, às vezes recicladas por processos sedimentares.

Palavras-chave: Bacia Bauru; Geoquímica; Proveniência; Intemperismo. 


\section{INTRODUCTION}

The Bauru Basin is located in southeastern Brazil, and its substrate consists of Early Cretaceous volcanic rocks from the central-northern Paraná Basin. The total area of the basin is $370,000 \mathrm{~km}^{2}$ (Figure 1), and its maximum sediment thickness is about $300 \mathrm{~m}$ (Batezelli, 2017). This basin was originated in the Late Cretaceous, as a result of flexural deformation in the south/southeast of the Alto Paranaíba Uplift (SAP), in western Minas Gerais (Batezelli, 2017). The Upper Cretaceous São Carlos Formation is a local unit in the eastern border of the Bauru Basin, which mainly comprises greenish siltstones and black shales, the latter rich in fossils, such as conchostracans, ostracods, pollen grains, and plant fragments (Castro et al., 2002; Arai and Dias-Brito, 2018). Due to its local occurrence, the São Carlos Formation has no scale to be contained in the lithostratigraphic map (Figure 1). Remarkable is the 6-m-thick interval of fossiliferous black shales, making this unit poorly understood in the tectono-sedimentary context of the Bauru Group. Shales indicate a deep lake where the depositional system remained for a long time without receiving sediment flow, accumulating large amounts of organic matter. Previous studies in the area address the fossiliferous content and depositional conditions (Castro et al., 2002). Because of similarities between the mudstone facies in São Carlos and Araçatuba formations (Batezelli et al., 2003; Batezelli, 2010, 2017; Albarelli et al., 2015) in western São Paulo State, a working hypothesis is that the São Carlos Formation correlates to the Araçatuba Formation, being thus part of the lowermost interval of the Bauru Group (Figure 2).

Studies carried out in time-equivalent successions elsewhere in the Bauru Group (e.g., Mattos, 2014; Mattos and Batezelli, 2014) presented geochemical information that served to identify the provenance and interpret the tectonosedimentary setting of the São Carlos Formation. Possible source areas for these sediments include magmatic rocks in the Rondonópolis Anteclise to the north, the Alto Paranaíba



Source: adapted from Batezelli (2017).

Figure 1. Lithostratigraphic map of the Bauru Basin. 
Uplift to the northeast, and the Serra do Mar Uplift to the east (Figure 1, Menegazzo et al., 2016). Were performed sedimentological and geochemical (Godoy et al., 2017; Quintão et al., 2017) studies on the stratotype of the São Carlos Formation aiming to identify its provenance and make inferences regarding the tectono-sedimentary context in the easternmost region of the Bauru Basin.

\section{GEOLOGICAL SETTING}

The Bauru Basin is one of the most documented and studied sedimentary basins in Brazil, with available data including more than 500 outcrop descriptions (by Fernandes, 1998; Batezelli, 2003) and 1269 well-logs
(180 presented by Paula e Silva et al., 2005; 140 by Batezelli, 2003; 135 by Batezelli, 2017; 814 by Batezelli and Ladeira, 2016; Batezelli et al., 2019) (Figure 1). This basin was developed during the Upper Cretaceous, in the central-south portion of the South American Platform, by thermomechanical subsidence (Riccomini, 1995, 1997; Fernandes and Coimbra, 1996; Fernandes, 1998). Sedimentation in the Bauru Basin occurred in two main phases, the first in essentially desert conditions, and the second in semi-arid with a greater presence of water (Fernandes, 1998). It is constituted by two secondorder (Figure 2) continental sequences deposited from Early to Late Cretaceous (Batezelli, 2017). Sequence 1 (Caiuá Group) comprises the Goio Erê, Rio Paraná, and Santo Anastácio formations, and was deposited by

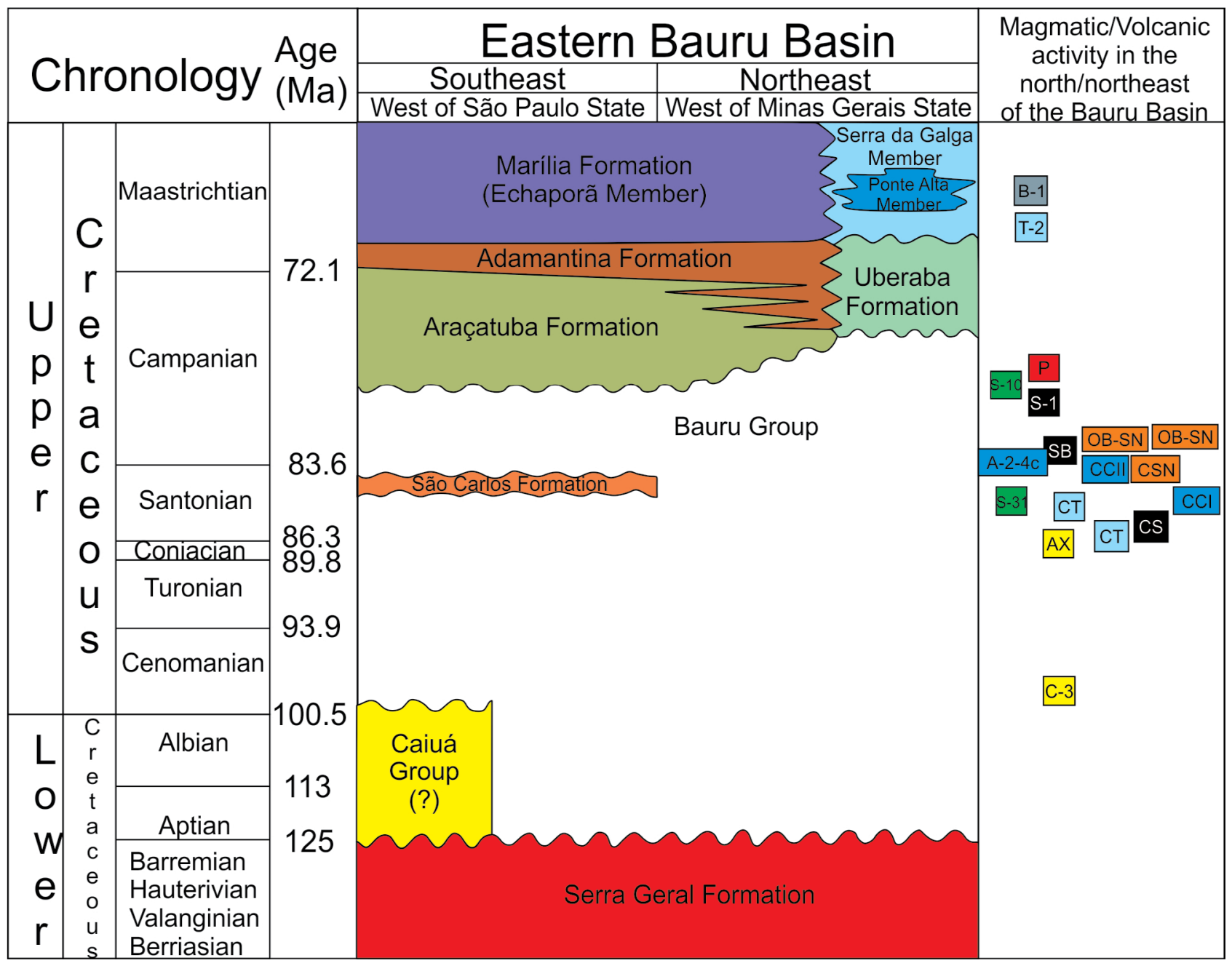

Source: adapted from Batezelli (2017).

Figure 2. Chronostratigraphic chart of the Cretaceous sequence in southern Brazil, based on Amaral et al. (1967) - sample CSN; Hasui and Cordani (1968) - samples AX, C-3, S-10, S-31, A-2-4c, OB-SN, SB, S-1, P, T-2, B-1; Sonoki and Garda (1988) - samples CT, CS, CCl; Machado Junior (1992) - sample CCll; Guimarães et al. (2012); Fragoso et al. (2013). 
aeolian processes in the Early Cretaceous (Batezelli, 2017). Sequence 2 (Bauru Group) is a record of the Late Cretaceous lacustrine system (Araçatuba and São Carlos formations), associated with a distributive fluvial system (Adamantina, Uberaba, and Marília formations) (Fernandes, 1998; Batezelli and Ladeira, 2016; Batezelli, 2017; Batezelli et al., 2019).

The base of the Bauru Group has muddy rocks from the Araçatuba Formation that pass upwards to and are partially interdigitated with sandstones and gravelly sandstones of the Adamantina/Uberaba and Marília formations (Figure 2). The deposits that make up the Bauru Group include both water- and wind-lain facies accumulated under semi-arid to arid climatic conditions. According to Batezelli (2003, 2017) and Batezelli et al. (2006), the stratigraphic architecture of the Bauru Basin indicates an evolution with alternated high- and low-accommodation systems and interaction of beach-lake environments and alluvial plains dominated by braided rivers.

The chronostratigraphy of the Bauru Group (Figure 2) is based on microfossils, vertebrates, and geochronological information from associated volcanic rocks. The Araçatuba Formation has been defined as Campanian-Maastrichtian (Gobbo-Rodrigues, 2001) (Figure 2). The Araçatuba Formation is a lacustrine association composed of greenish-brown, very fine sandstones and siltstones that may be massive or present plane-parallel and small-sized crossstratification. The thickness varies from $30 \mathrm{~m}$ in outcrops to $75 \mathrm{~m}$ in the subsurface, and the contact with the underlying Serra Geral Formation and Caiuá Group is unconformable (Batezelli et al., 2003).

The São Carlos Formation was defined by Castro et al. (2002) based on a 39-m-thick section in the Nossa Senhora de Fátima farm, São Carlos region, in the easterncentral part of the state of São Paulo. Mezzalira (1974) first described this succession as an interval composed of dark gray sandstone at the base, followed by clayey siltstones, shales, and a topmost red silty-clay. The author also reported the occurrence of gastropods, bivalves, conchostracans, and ostracods.

According to Castro et al. (2002), the São Carlos Formation lies on an unconformity of the Serra Geral Formation volcanics and is capped by a weathering profile. The section is separated into three basic units:

I. lower sandy interval, consisting of gray-greenish sandstones with poorly preserved parallel laminations, wave ripples, and bioturbations;

II. Nossa Senhora de Fátima member, composed of sandyclayey and silty-clayey rhythmites of dark-gray color and with the presence of ostracods (carapaces and molds), conchostracans, fragments of vertebrates, mollusks (molds of microgastropods and bivalves), and plant remains;
III. upper sandy interval, comprising fine to very coarsegrained sandstone with cross or plane-parallel lamination. Castro et al. (2002) interpreted it as semi-arid paleoclimate due to the presence of ephedroid pollen grains. Based on palynomorphs (Lima et al., 1986; Castro et al., 2002), the age of deposition can be placed in the Coniacian-Santonian interval. A more recent study dealing with palynomorphs retrieved from shale (Arai and Dias-Brito, 2018) indicates an Upper Santonian age for the São Carlos Formation.

\section{MATERIALS AND METHODS}

The studied area encompasses the Nossa Senhora de Fátima farm (Figure 3), where the São Carlos Formation lies on basalts of the Serra Geral Formation (Lower Cretaceous) and is covered by sandstones and ferricretes from the Itaqueri Formation (Paleocene).

A 23-m-thick sedimentary succession was studied through facies analysis and bulk geochemistry. A vertical stratigraphic profile was measured (Figure 3), and a total of 18 samples were collected according to five different lithotypes: sandstone 1 (two samples), sandstone 2 (one sample), siltstone (five samples), claystone (three samples), and shale (seven samples). The profile was carried out in the same outcrop location where Castro et al. (2002) defined the São Carlos Formation.

Was conducted a bulk-geochemical analysis of major and minor elements using an X-ray fluorescence spectrometry (Philips - PW 2404) at the Geochemistry Laboratory of the Geosciences Institute at Unicamp. Duplicates of some samples were assessed in parallel to check accuracy and reproducibility. Accuracy data were obtained from duplicates of real samples and those of veracity of laboratory results in ten rounds of the GeoPTTM proficiency test of the International Association of Geoanalysts (IAG).

Was estimated the degree of chemical weathering by dosing the Chemical Index of Alteration (CIA) defined by Nesbitt and Young (1982), which uses the oxides $\mathrm{Al}_{2} \mathrm{O}_{3}$, $\mathrm{CaO}, \mathrm{Na}_{2} \mathrm{O}$, and $\mathrm{K}_{2} \mathrm{O}$ to evaluate the degree of weathering of source rocks (Equation 1):

$\mathrm{CIA}=\left[\mathrm{Al}_{2} \mathrm{O}_{3} /\left(\mathrm{Al}_{2} \mathrm{O}_{3}+\mathrm{CaO} *+\mathrm{Na}_{2} \mathrm{O}+\mathrm{K}_{2} \mathrm{O}\right)\right] \times 100$

In which $\mathrm{CaO}^{*}$ is defined as the concentration of silicates from the Equation 2:

$\mathrm{CaO}^{*}=\mathrm{CaO}-\left(10 / 3 \mathrm{P}_{2} \mathrm{O}_{5}\right)$

If the value found for $\mathrm{CaO}^{*}$ is greater than the one for $\mathrm{Na}_{2} \mathrm{O}$, then the value used is equal to that of $\mathrm{Na}_{2} \mathrm{O}$. In the calculations performed, the oxide values were obtained in molecular percentages. 


\section{DATA DESCRIPTION}

\section{Sedimentary facies}

The 23-m-thick stratigraphic section exposes a succession of shales, claystones, siltstones, and sandstones lying on the Serra Geral Formation basalts by means of a largely weathered horizon (Figure 4). We identified five sedimentary facies:

I. Parallel-stratified sandstones consisting of 3.00 to 3.30-m-thick greyish/greenish, very fine-grained sandstone with a silty matrix, sub-rounded grains, sand-filled bioturbations, 5-cm-thick parallel stratification, iron nodules up to $15 \mathrm{~cm}$ in diameter and disposed in lenticular, amalgamated beds;

II. Sandstones with low-angle cross-stratification composed of fine to very fine-grained, well-sorted, white to orange sandstones with mottled clay portions, rounded to sub-rounded grains, micaceous minerals, and up to 2-m-large low-angle cross-stratification or parallel stratification;

III. Massive siltstones comprising 1.00 to 2.30 -m-thick greenish siltstones lacking sedimentary structures;

IV. Claystones consisting of massive, reddish or greenish claystones up to $3.00-\mathrm{m}$-thick with thin sheets of micaceous minerals;
V. Shales in the form of a 5.00-m-thick unit of black and fossiliferous shale, including undifferentiated fossil material and plant remains (Figure 4).

\section{Geochemical characterization}

\section{Major and minor elements}

Table 1 presents the chemical analysis results of total rock of major and minor elements as percentage of oxide mass fraction ( $\mathrm{wt} \%)$. Silica is the element with the highest percentage, ranging from 31.42 to $83.1 \%$, with a mean value of $56.89 \%$. This large variation is due to the presence of samples like sandstones and siltstones, which have higher amounts of silica and lower percentages of alumina. The more clayey samples have less silica and more alumina than, for instance, samples from shale facies. Alumina varies from 5.17 to $15.77 \%$, with a mean of $13.36 \%$. The proportions of silica and alumina are inversely proportional. Figure 5 highlights these relationships, with a constructed geochemical profile indicating elementary variations according to the stratigraphic profile. The highest occurrences of $\mathrm{Fe}_{2} \mathrm{O}_{3}$ are in the most oxidized, reddish samples, with values ranging from 11.88 to $18.94 \%$ and a mean of $8.78 \%$. Calcium has a mean value of $2.44 \%$ and higher incidence in claystone facies. The relationship between $\mathrm{K}_{2} \mathrm{O} / \mathrm{Na}_{2} \mathrm{O}$ is used to

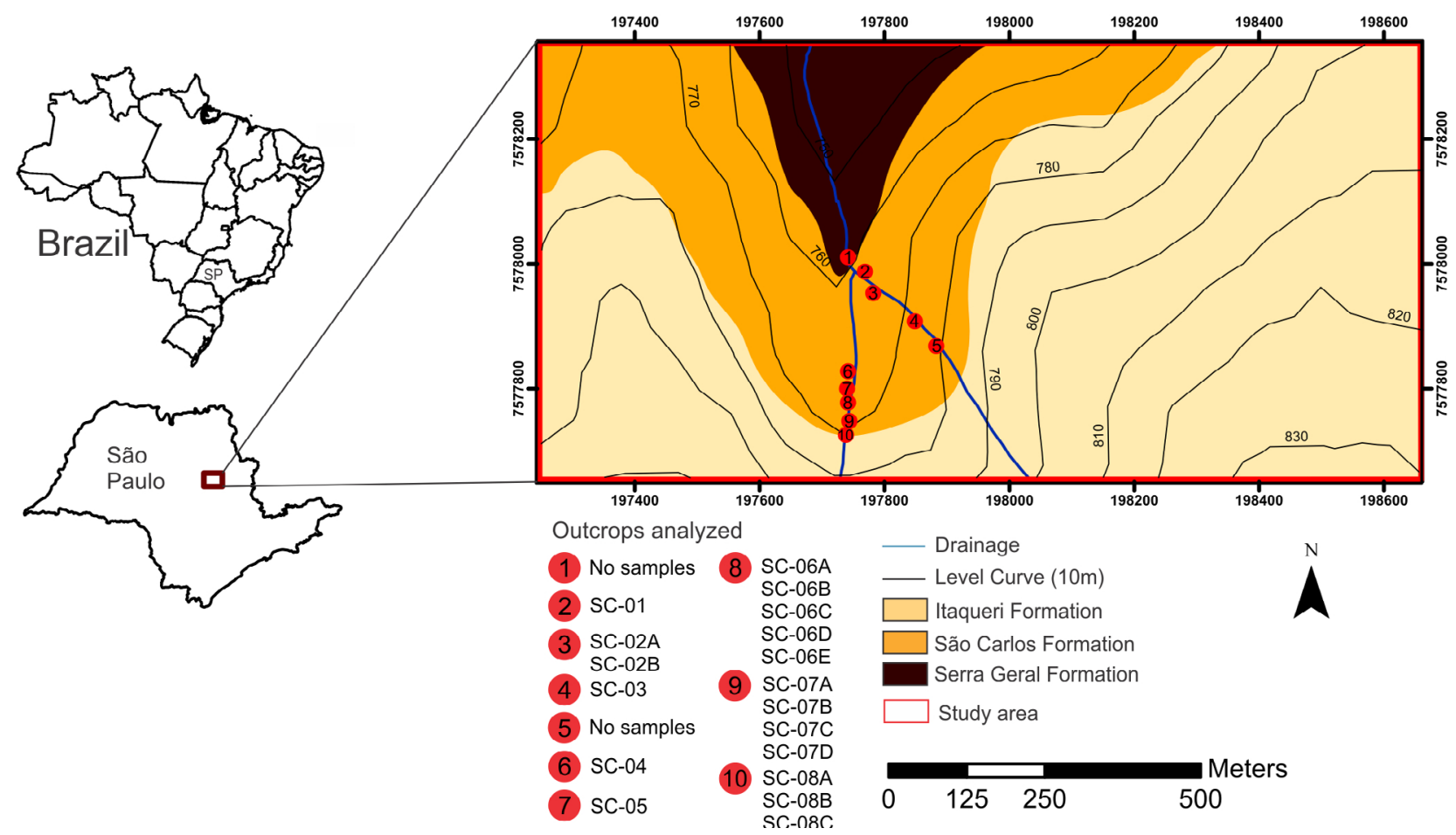

Figure 3. Location and simplified geological setting of the study area. 
compare the amount of potassium feldspar and plagioclase (Mattos, 2014). The higher this ratio, the greater the occurrence of potassium feldspar in facies with coarser grain sizes like sandstone and siltstones. Magnesium oxide has a higher occurrence in more clayey samples, whereas titanium oxide concentrates in sandier ones. $\mathrm{P}_{2} \mathrm{O}_{5}$ and $\mathrm{MnO}$ values are overall low, indicating no significant variation with respect to facies types. Anomalies in trace elements in SC-02B represent the presence of heavy minerals, such as monazite. Regarding the $\mathrm{SC}-04$ sample, the high value of loss on ignition (LOI) and $\mathrm{CaO}$ indicates the presence of

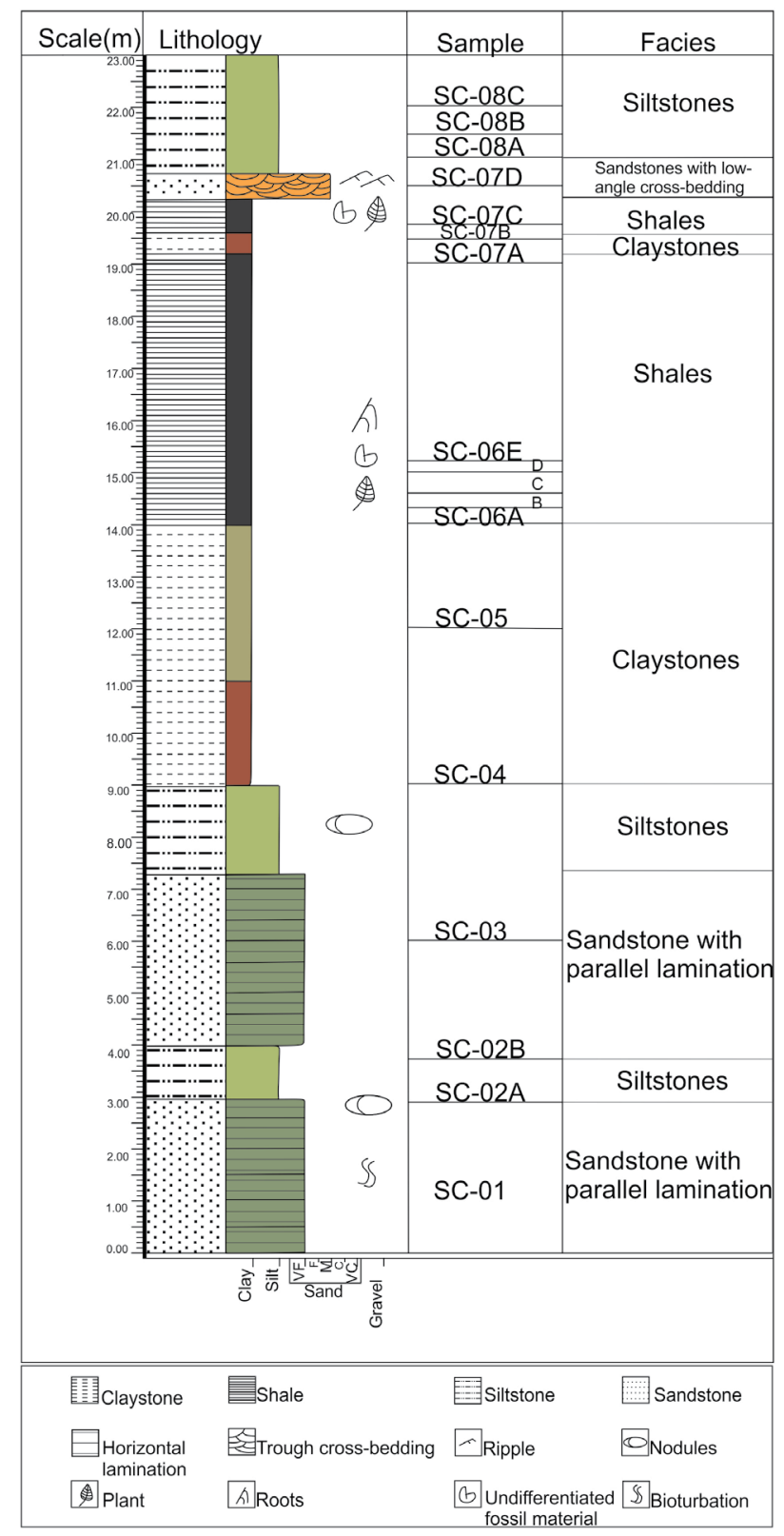

Figure 4. Vertical stratigraphic profile of the São Carlos Formation. organic matter. If the LOI were normalized, oxide values would be within the standard range.

Correlation coefficients between major elements (Table 2) showed that $\mathrm{SiO}_{2}$ has a pronounced negative correlation with $\mathrm{Al}_{2} \mathrm{O}_{3}(\mathrm{r}=-0.33), \mathrm{Fe}_{2} \mathrm{O}_{3}(\mathrm{r}=-0.47), \mathrm{MgO}(\mathrm{r}=-0.50)$, and $\mathrm{P}_{2} \mathrm{O}_{5}$ $(\mathrm{r}=-0.33)$; unmarked with $\mathrm{K}_{2} \mathrm{O}(\mathrm{r}=-0.12), \mathrm{TiO}_{2}(\mathrm{r}=-0.17)$, and $\mathrm{Na}_{2} \mathrm{O}(\mathrm{r}=-0.15)$; and strong $(\mathrm{r} \leq-0.60)$ negative correlation with $\mathrm{CaO}(\mathrm{r}=-0.70)$ and $\mathrm{MnO}(\mathrm{r}=-0.60)$. The latter two strong correlations result from the presence of $\mathrm{CaO}$ in large quantities in claystone facies. This facies shows a high and positive correlation between $\mathrm{CaO}$ and $\mathrm{MnO}$, since both oxides are present in the same minerals.

An exception is the case of sandstones facies containing twice as much $\mathrm{TiO}_{2}$ as the average. This sample (SC-01) is in contact with basalt and may have undergone contamination, having contrasting values with the other samples. The positive correlation between $\mathrm{TiO}_{2}$ and $\mathrm{Al}_{2} \mathrm{O}_{3}$ indicates the association of residual products of $\mathrm{TiO}_{2}$-bearing phases with clay fraction or heavy minerals containing fine grain $\mathrm{TiO}_{2}$ (Roy and Roser, 2013).

\section{Trace elements}

Table 1 presents the results for trace elements and rare earth elements in ppm. The values are compared with their mean and also the mean values of Post-Archean Australian Shale (PAAS), by Taylor and McLennan (1985), representative of the average composition of the Continental Crust.

Multi-elemental graphs were elaborated to analyze trace elements and rare earths, with elements normalized by PAAS and compared to groups of Large Ion Lithophile Elements (LILE), High Field Strength Elements (HFSE), Transition Trace Elements (TTE), and Rare Earth Elements (REE), as shown in Figure 6.

\section{Large Ion Lithophile Elements (LILE): Rb, Ba, Sr, Th}

Comparing the values obtained with PAAS values, it is possible to notice differences in the concentrations between LILE. $\mathrm{Rb}$ presents values close to those of PAAS, with most of the facies impoverished and few enriched, and a mean value of $139.22 \mathrm{ppm}$ compared to a PAAS of 160 ppm (Table 1, Figure 6A). The samples with finer grain sizes have higher $\mathrm{Rb}$ enrichment when compared with coarser-grained samples. As LILE are affected by weathering, $\mathrm{Rb}$ may have been incorporated into the clays, as it had a high positive correlation with $\mathrm{Al}_{2} \mathrm{O}_{3}(\mathrm{r}=0.61)$ and $\mathrm{MgO}(\mathrm{r}=0.74)$ (Appendix 1).

The Ba element has a mean value of $1,022.83 \mathrm{ppm}$, enriched in comparison to PAAS (650 ppm), and strong possible correlations with $\mathrm{K}_{2} \mathrm{O}(0.82)$, $\mathrm{Ce}(0.90), \mathrm{La}(0.68)$, $\mathrm{Nb}(0.75), \mathrm{Nd}(0.64)$, and $\mathrm{Th}(0.71)$. Sr has a mean value of $223.50 \mathrm{ppm}$, with little enrichment compared to PAAS 


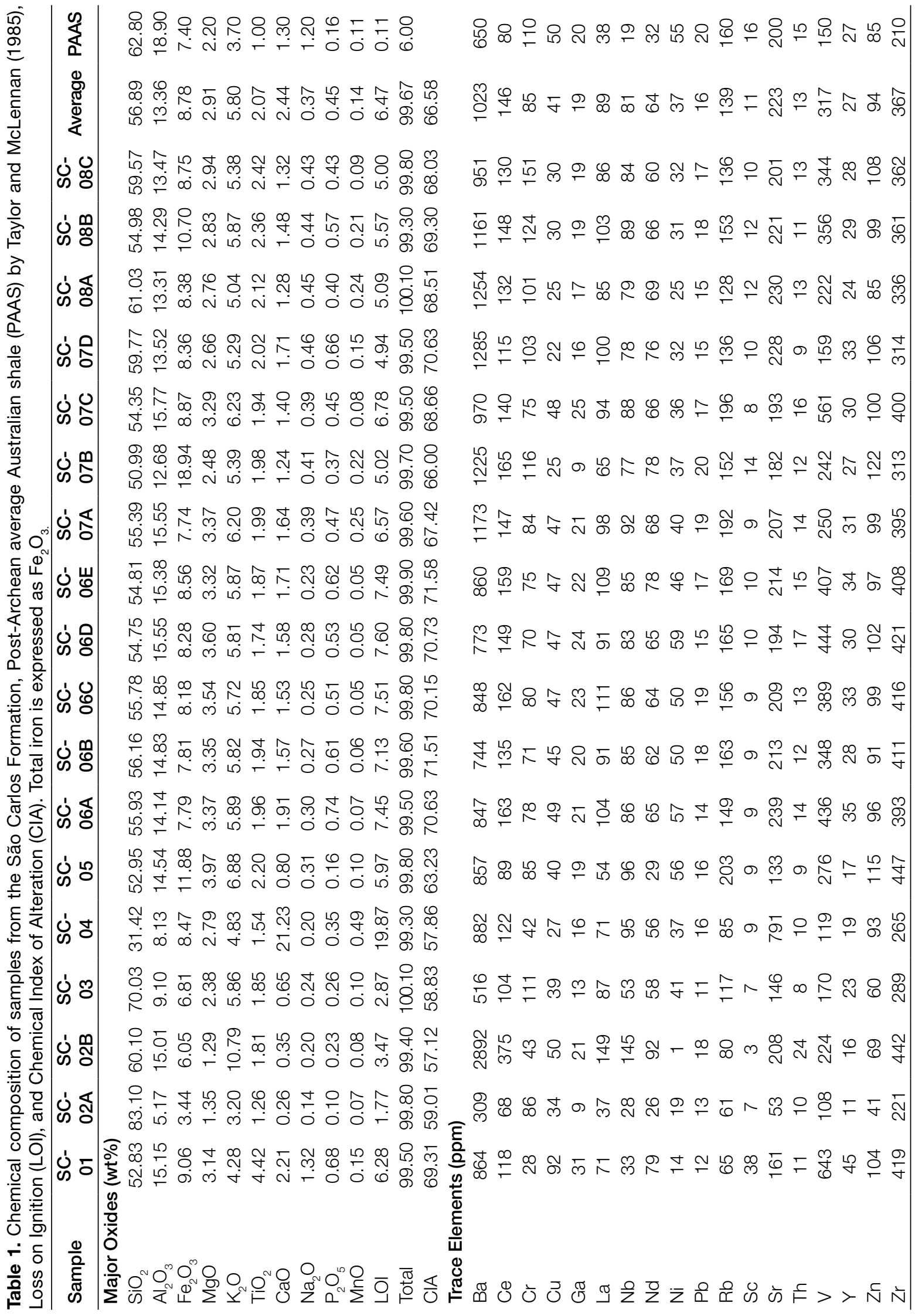


(200 ppm). Sr enrichment occurs in only one sample due to the high $\mathrm{CaO}$ value, positive correlation of $\mathrm{Sr}$ with $\mathrm{CaO}$ $(\mathrm{r}=0.97)$ and $\mathrm{MnO}(\mathrm{r}=0.79)$, indicating an association with post-depositional carbonates or carbonate-enriched layers. The positive correlation between $\mathrm{Al}_{2} \mathrm{O}_{3}, \mathrm{Ba}$, and $\mathrm{Sr}$ results from the presence of phyllosilicates (Roy and Roser, 2013). Concentrations of Th are impoverished compared to PAAS (mean value of $13.09 \mathrm{ppm} \times 14.6 \mathrm{ppm}$ ), with only siltstone facies being enriched in Th. The Th element has strong positive correlations with $\mathrm{K}_{2} \mathrm{O}, \mathrm{Ba}, \mathrm{Ce}$, and $\mathrm{La}$, as highlighted in bold in Appendix 1.

\section{High Field Strength Elements (HFSE): Zr, Y, Nb}

HFSE present variable behaviors when compared to PAAS values (Figure 6B). The mean value of $\mathrm{Zr}$ is $367.69 \mathrm{ppm}$, enriched in comparison to the $210 \mathrm{ppm}$ PAAS value, and it has a strong correlation coefficient with $\mathrm{Al}_{2} \mathrm{O}_{3}(\mathrm{r}=0.90)$.

Table 2. Correlation between oxides.

\begin{tabular}{lcccccccccc}
\hline & $\mathrm{SiO}_{2}$ & $\mathrm{Al}_{2} \mathrm{O}_{3}$ & $\mathrm{Fe}_{2} \mathrm{O}_{3}$ & $\mathrm{MgO}$ & $\mathrm{K}_{2} \mathrm{O}$ & $\mathrm{TiO}_{2}$ & $\mathrm{CaO}$ & $\mathrm{Na}_{2} \mathrm{O}$ & $\mathrm{P}_{2} \mathrm{O}_{5}$ & $\mathrm{MnO}$ \\
\hline $\mathrm{SiO}_{2}$ & 1 & & & & & & & & & \\
$\mathrm{Al}_{2} \mathrm{O}_{3}$ & -0.33 & 1 & & & & & & & & \\
$\mathrm{Fe}_{2} \mathrm{O}_{3}$ & -0.47 & 0.27 & 1 & & & & & & \\
$\mathrm{MgO}$ & -0.5 & 0.59 & 0.29 & 1 & & & & & & \\
$\mathrm{~K}_{2} \mathrm{O}$ & -0.12 & 0.48 & -0.01 & -0.13 & 1 & & & & & \\
$\mathrm{TiO}_{2}$ & -0.17 & 0.39 & 0.21 & 0.25 & -0.14 & 1 & & & \\
$\mathrm{CaO}$ & -0.7 & -0.38 & 0 & 0.03 & -0.19 & -0.15 & 1 & & \\
$\mathrm{Na}_{2} \mathrm{O}$ & -0.15 & 0.31 & 0.21 & 0.18 & -0.27 & 0.97 & -0.11 & 1 & \\
$\mathrm{P}_{2} \mathrm{O}_{5}$ & -0.33 & 0.57 & 0.09 & 0.51 & -0.16 & 0.42 & -0.04 & 0.43 & 1 & \\
$\mathrm{MnO}$ & -0.6 & -0.32 & 0.25 & -0.07 & -0.22 & 0 & 0.8 & 0.09 & -0.09 & 1 \\
\hline
\end{tabular}

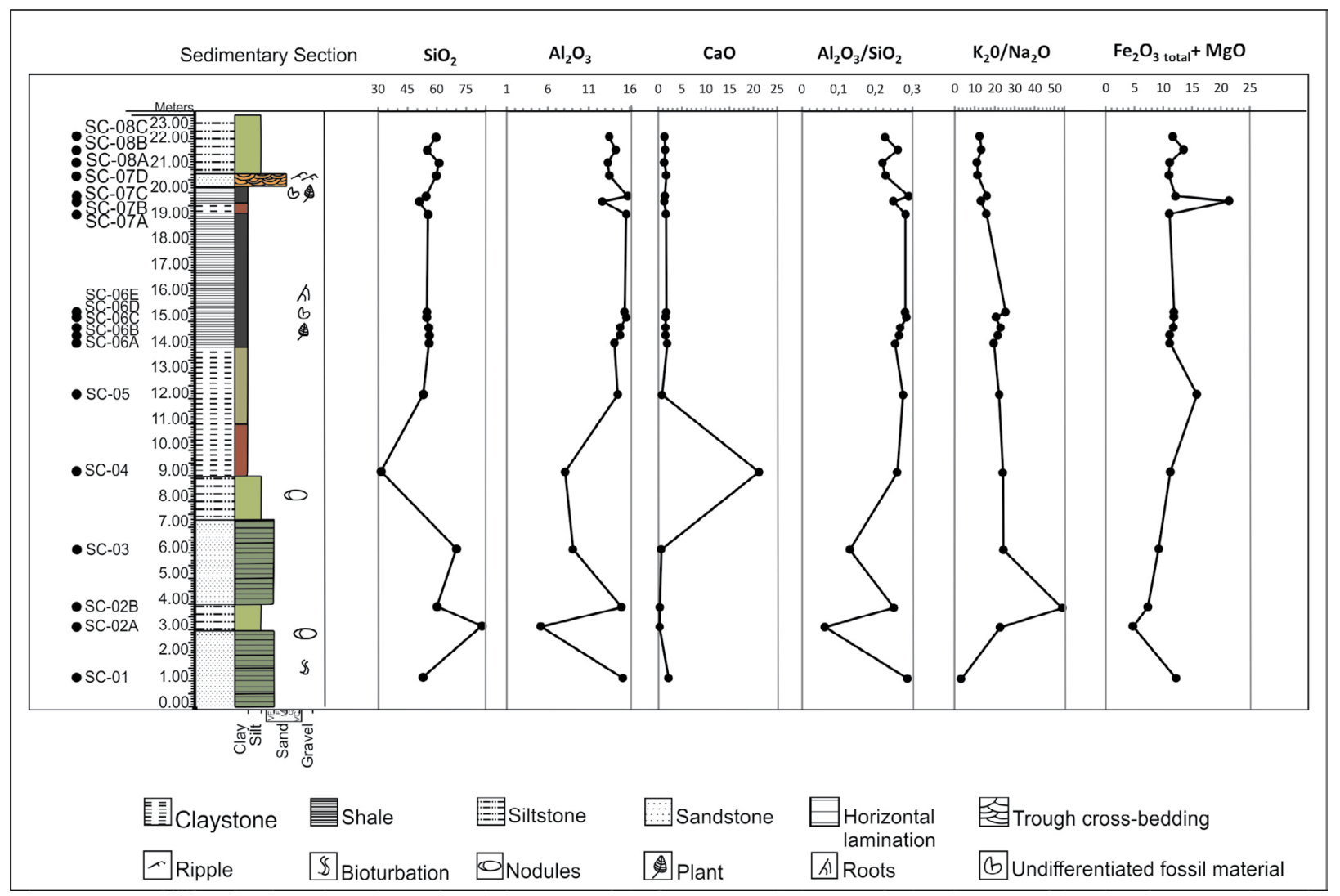

Figure 5. Geochemical profile of major elements $\left(\mathrm{SiO}_{2}, \mathrm{Al}_{2} \mathrm{O}_{3}, \mathrm{CaO}\right)$ and $\mathrm{Al}_{2} \mathrm{O}_{3} / \mathrm{SiO}_{2}, \mathrm{~K}_{2} \mathrm{O} / \mathrm{Na}_{2} \mathrm{O}$, and total Fe $\mathrm{O}_{3}+\mathrm{MgO}$ ratios from the São Carlos Formation samples in the study area and their position in the described columnar section. 
This finding may indicate the presence of this element in claystones. $\mathrm{Zr}$ is also positively correlated with $\mathrm{Ga}(\mathrm{r}=0.79)$ and $\mathrm{V}(\mathrm{r}=0.67)$, as indicated in Appendix 1. Y has a mean value of $27.33 \mathrm{ppm}$, similar to the $27 \mathrm{ppm}$ PAAS value, and strong positive correlations with $\mathrm{Al}_{2} \mathrm{O}_{3}, \mathrm{TiO}_{2}, \mathrm{P}_{2} \mathrm{O}_{5}$, and $\mathrm{Ga} . \mathrm{Nb}$ is enriched when compared to PAAS $(81.23 \mathrm{ppm}$ versus $19 \mathrm{ppm}$ ), although this enrichment is less expressive in sandstone facies. $\mathrm{Nb}$ has a high positive correlation with the elements $\mathrm{K}_{2} \mathrm{O}, \mathrm{Ba}, \mathrm{Pb}, \mathrm{Th}, \mathrm{Ce}$, and $\mathrm{La}$ (Appendix 1).

\section{Transition Trace Elements (TTE): Cr, Ni, V, Sc, Cu}

TTE have a diverse distribution, with $\mathrm{Cr}, \mathrm{Ni}, \mathrm{Sc}$, and $\mathrm{Cu}$ impoverished in comparison to PAAS (Figure 6C) and mean values equal to $84.62 \mathrm{ppm}, 36.87 \mathrm{ppm}, 10.83 \mathrm{ppm}$, and $41.38 \mathrm{ppm}$, respectively (Table 1 ). However, V, with an average of $316.56 \mathrm{ppm}$, is enriched compared to PAAS $(150 \mathrm{ppm})$, mainly in shale facies. $\mathrm{V}$ has a positive correlation with several elements, such as $\mathrm{Al}_{2} \mathrm{O}_{3}, \mathrm{TiO}_{2}, \mathrm{P}_{2} \mathrm{O}_{5}$, $\mathrm{Zr}, \mathrm{Cu}, \mathrm{Ga}$, and $\mathrm{Y}$.
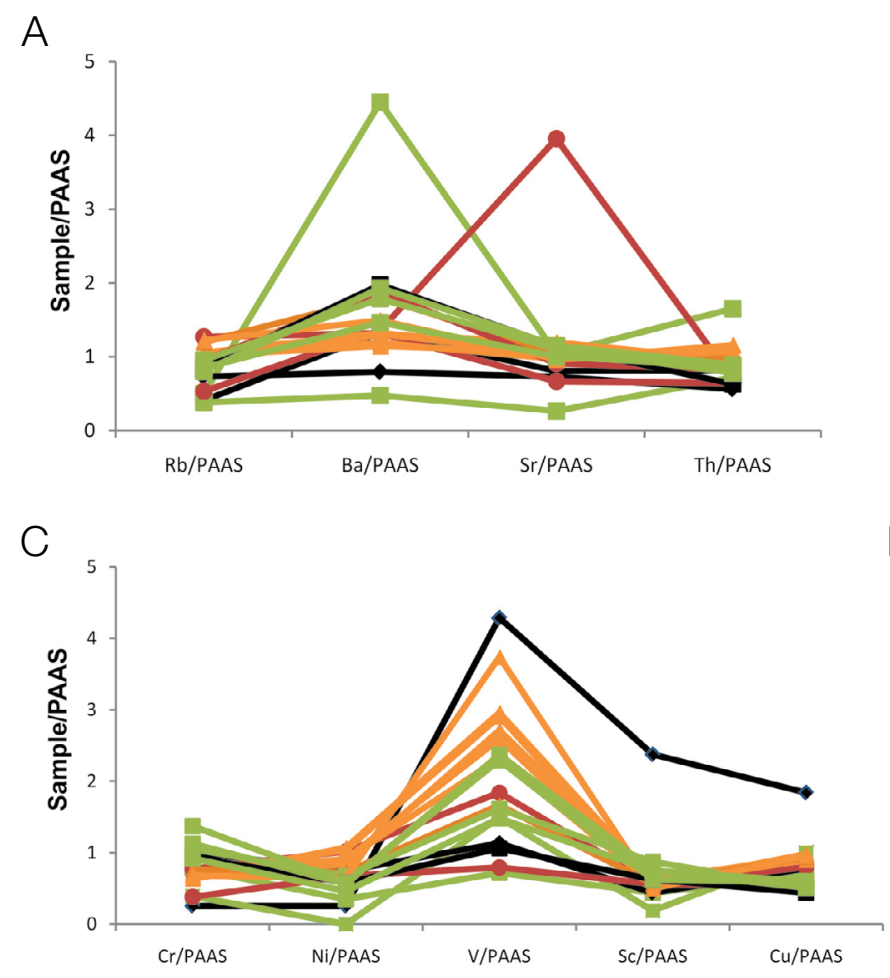

\section{Rare Earth Elements (REE)}

The detected REE include only light elements (LREE), such as $\mathrm{La}, \mathrm{Ce}$, and $\mathrm{Nd}$. They are enriched in comparison to PAAS, with mean values of $89.22 \mathrm{ppm}, 145.61 \mathrm{ppm}$, and $64.28 \mathrm{ppm}$, respectively (Figure 6D). Shale facies are more enriched in LREE than other facies, a pattern that may suggest that clays control the distribution of LREE (Akarish and El-Gohary, 2011). The positive correlations of LREE include La: $\mathrm{K}_{2} \mathrm{O}$, La: Ba, La: Ce, La: Nb, La: Nd, Ce: Ba, Ce: $\mathrm{Nd}, \mathrm{Ce}: \mathrm{K}_{2} \mathrm{O}$, and $\mathrm{Nd}: \mathrm{Ba}$.

\section{DATA INTERPRETATION}

\section{Depositional setting}

Considering the facies succession in the area, a lacustrine depositional environment can be indicated for the São Carlos Formation. The presence of bioturbations suggests an overall

B

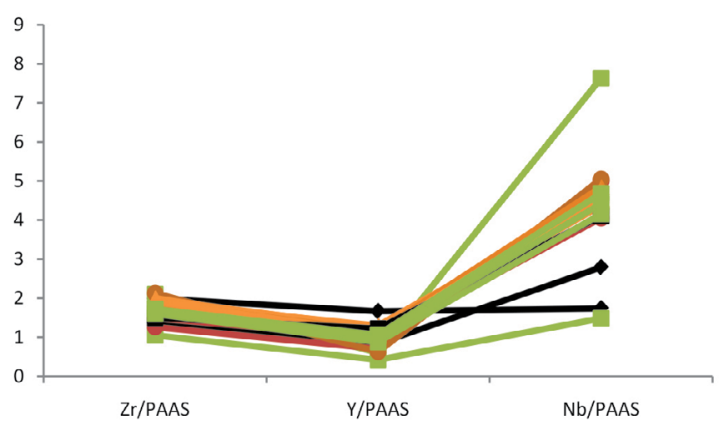

D

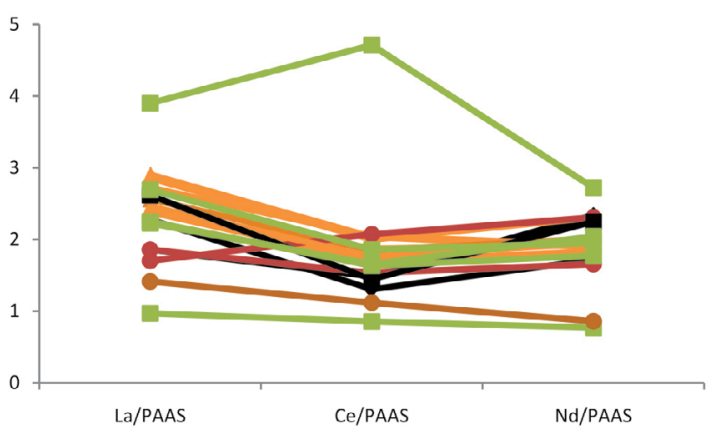

Figure 6. Multi-elemental diagrams of trace elements and rare earths: (A) Diagram of Large lon Lithophile Elements: Rb, $\mathrm{Ba}, \mathrm{Sr}$, Th compared to Post-Archean Australian Shale (PAAS) values from the São Carlos Formation samples. (B) Diagram of High Field Strength Elements: Zr, Y, Nb compared to PAAS values from the São Carlos Formation samples. (C) Diagram of transition trace elements: $\mathrm{Cr}, \mathrm{Ni}, \mathrm{V}, \mathrm{Sc}, \mathrm{Cu}$ compared to PAAS values from the São Carlos Formation samples. (D) Diagram of Rare Earth Elements: La, Ce, Nd compared to PAAS values from the São Carlos Formation samples. 
oxygenated environment; however, the 5-m-thick black shale unit points to a period of deeper water column, low supply, and poorly oxygenated bottom to promote organic matter accumulation and preservation. Vertical grain-size alternations in the whole section are interpreted as a result of changes in sediment discharge to the lake associated with variations in the energy of incoming flows. Low-angle cross-stratified sandstones with very fine, well-sorted, subrounded quartz grains are regarded as windblown deposits formed during stages of lake contraction.

\section{Sedimentary classification}

With the geochemical data from the São Carlos Formation samples, we could classify them using the SandClass diagram (Herron, 1988). This classification allows us to differentiate high-grade systems rich in quartz from low-grade shales rich in clay, create a mineralogical record between $\mathrm{Fe}_{2} \mathrm{O}_{3} / \mathrm{K}_{2} \mathrm{O}$ to distinguish lithic fragments from feldspars, as well as have an indication of mineral stability. Using the SandClass system, the samples were classified as shale, ferruginous shale, and litharenite (Figure 7).

The lithological classification presented in Figure 4 resulted from the macroscopic and magnifying analysis of samples collected in the field. The rates are divergent, which may have been due to a large amount of silt matrix in the sandstones, more $\mathrm{Al}_{2} \mathrm{O}_{3}$ in the sandstone matrix, and being classified as shales by the SandClass system. In sandstones samples, the $\mathrm{SiO}_{2}$ values are not high, so the low $\mathrm{SiO}_{2} / \mathrm{Al}_{2} \mathrm{O}_{3}$ ratio is positioned in the shales.

\section{Source area weathering indices and weathering trends}

The CIA values in the São Carlos Formation range from 57.12 to 71.58 (Table 1), suggesting moderate weathering intensity. The degree of chemical weathering of rocks is the result of several factors, such as climate and transport (Nesbitt and Young,

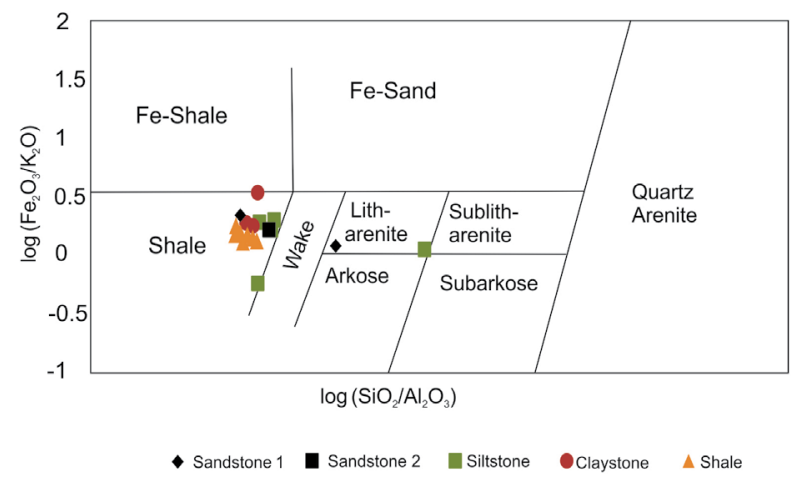

Figure 7. Geochemical classification by the SandClass system, Herron (1988), from the São Carlos Formation samples.
1982). During chemical weathering, mobile cations like $\mathrm{Na}^{+}$ and $\mathrm{Ca}^{2+}$ tend to be lost while cations such as $\mathrm{Al}^{3+} \mathrm{e} \mathrm{Ti}^{4+}$ are retained (Moradi et al., 2016), resulting in higher CIA values.

The CIA values for the analyzed samples were plotted on the ternary diagram A-CN-K (Figure 8), proposed by Nesbitt and Young (1984), in which $\mathrm{A}=\mathrm{Al}_{2} \mathrm{O}_{3}(\mathrm{~mol} \%), \mathrm{CN}=\mathrm{CaO}^{*}$ $+\mathrm{Na}_{2} \mathrm{O}(\mathrm{mol} \%)$, and $\mathrm{K}=\mathrm{K}_{2} \mathrm{O}(\mathrm{mol} \%)$. The findings suggest that the source rock weathering produced a considerable loss of $\mathrm{Na}$ and alumina enrichment. These changes also caused the potassium feldspar to lose $\mathrm{K}+$, increasing the alumina. All samples classified in the field as shale facies had the highest weathering indices, suggesting a warmer and more humid climate. Claystone and siltstone facies had lower weathering indices.

\section{Tectonic environment}

Trace elements were plotted to classify the tectonic environment of the source area in a $\mathrm{Th}-\mathrm{Sc}-\mathrm{Zr} / 10$ ternary diagram proposed by Bhatia and Crook (1986). Almost all samples fall in the passive continental margin of the tectonic field (Figure 9), meaning that the studied sediments derived from stable continental areas and were deposited in an intraplate setting (Mishra and Sem, 2012).

\section{Sedimentary provenance}

Using the discriminant functions of Roser and Korsch (1988) for major elements (Figure 10A), we classified the source rocks primarily as of recycled sedimentary provenance and secondarily as intermediate source rocks (two claystone

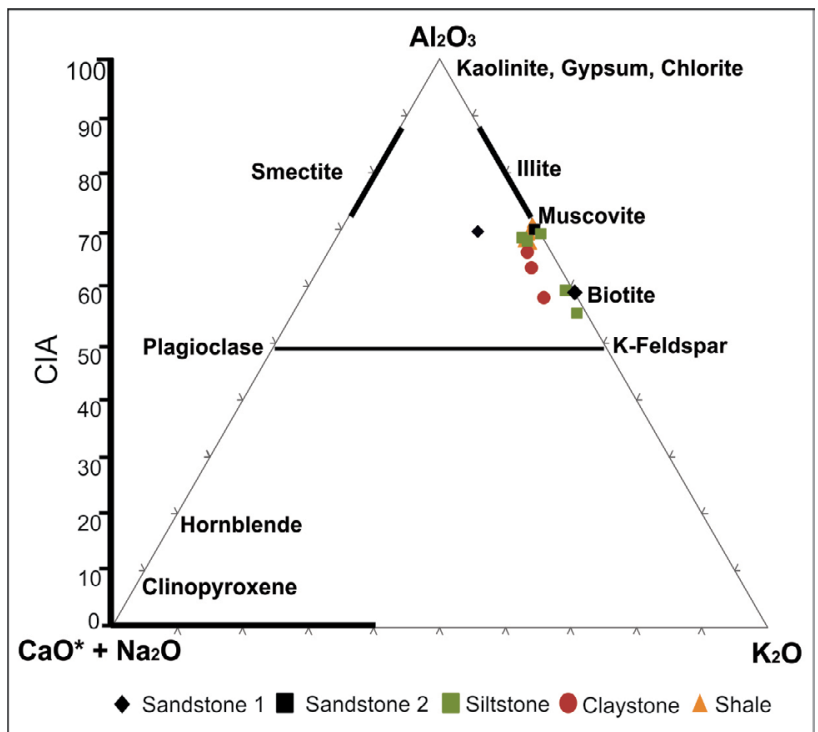

Figure 8. Ternary diagram $\mathrm{Al}_{2} \mathrm{O}_{3}-\left(\mathrm{CaO}^{*}+\mathrm{Na}_{2} \mathrm{O}\right)-\mathrm{K}_{2} \mathrm{O}$ with plots of the São Carlos Formation samples to determine weathering (Nesbitt and Young, 1984). 
samples). This classification indicates that these sediments suffered progressive loss of feldspar and increase of quartz due to recycling. The moderate weathering demonstrated by the diagram A-CN-K (Figure 8) shows that most of the feldspar was destroyed (Roy and Roser, 2013). The samples classified as intermediates probably underwent less reworking and/or could have derived from closer sources, as the basalts at the base of the sedimentary section and along the basin.

Stationary trace elements are used to estimate the primary composition of the source rock. McLennan et al. (1993) suggest that it is possible to evaluate the origin of mafic rocks, felsic rocks, and recycled sediments based on the $\mathrm{Zr} / \mathrm{Sc}-\mathrm{Th} / \mathrm{Sc}$ variation. For the São Carlos Formation samples, the provenance indicates felsic rocks and sedimentary recycling (Figure 10B). The high values of $\mathrm{Zr} / \mathrm{Sc}$ suggest intense weathering because zircon is very stable, while scandium is depleted for being less stable.

According to the $\mathrm{TiO}_{2} \mathrm{xZr}$ diagram (Hayashi et al., 1997, Figure 10C), we can conclude that source rocks have an intermediate to felsic character. Shale facies have more felsic sources than sandstones and siltstones, which are classified as intermediates. The values of the $\mathrm{TiO}_{2} / \mathrm{Zr}$ ratio for the finest grain-sized rocks are lower than 55, which classifies them as felsic rocks. However, these rocks also have higher weathering values, which may indicate greater reworking and not necessarily different provenances.

According to Garver et al. (1996), the low mean Cr-Ni values found in the São Carlos Formation $(\mathrm{Cr}=84.2 \mathrm{ppm}$; $\mathrm{Ni}=36.87 \mathrm{ppm}$ ), a Cr/Ni ratio of 1.14 to 4.72 , and a positive correlation $(\mathrm{r}=0.16)$ suggest a felsic provenance like granites and metasedimentary rocks.

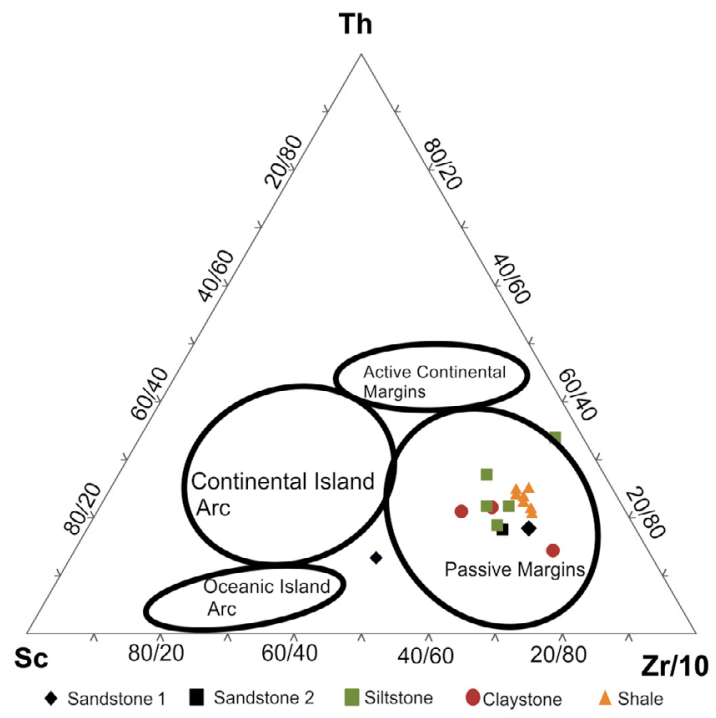

Figure 9. Diagram of tectonic discrimination Th-Sc$\mathrm{Zr} / 10$ (Bhatia and Crook, 1986) that classifies the studied samples as sourced from a passive continental margin.
The $\mathrm{La} / \mathrm{Sc}, \mathrm{Th} / \mathrm{Sc}$, and $\mathrm{Th} / \mathrm{Cr}$ ratios (Table 3) are good indicators of sedimentary provenance because of distinctive ranges between mafic and felsic rocks (Cullers, 1994, 2000).
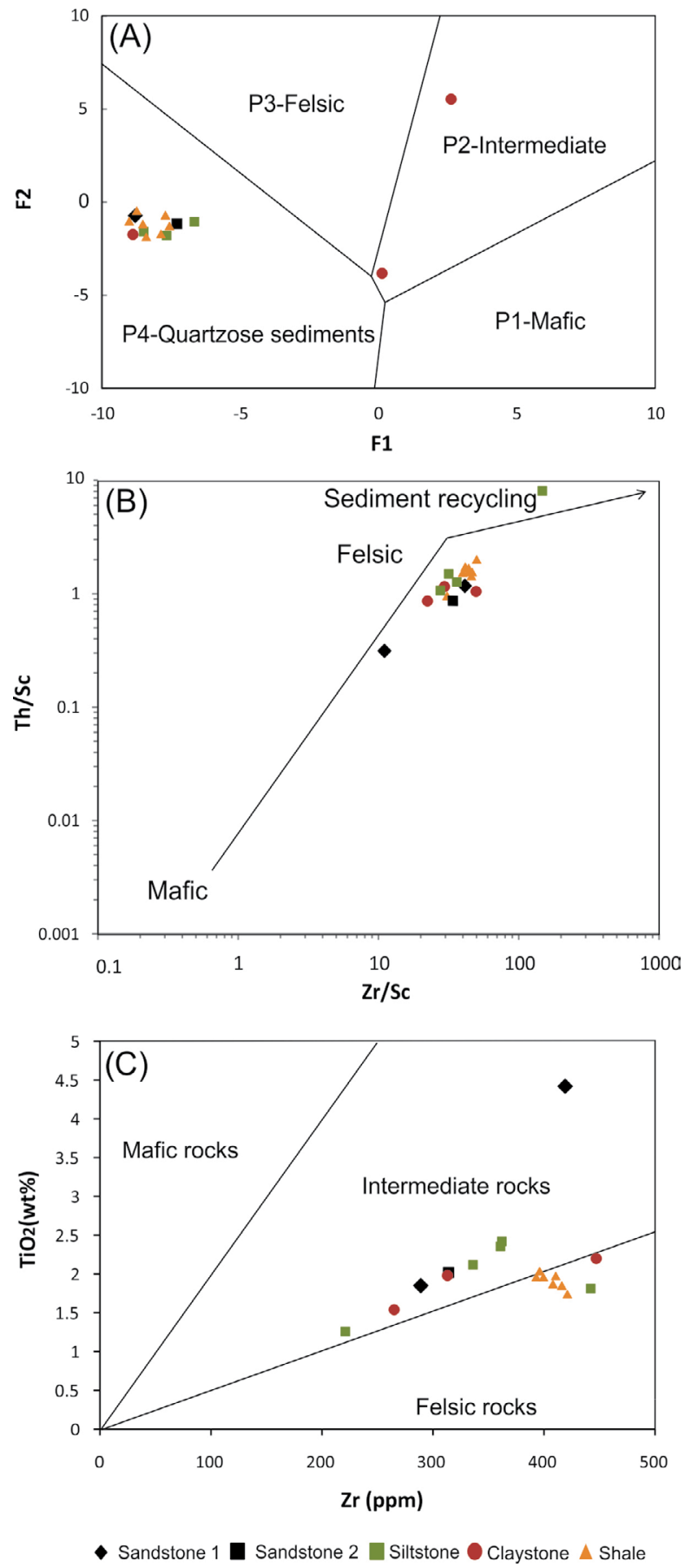

Figure 10. (A) Discriminant Function Diagram by Roser and Korsch (1988) of the São Carlos Formation samples. (B) Diagram Th/Sc-Zr/Sc (McLennan et al., 1993) of the São Carlos Formation samples. (C) Diagram $\mathrm{TiO}_{2}-\mathrm{Zr}$ (Hayashi et al., 1997) of the São Carlos Formation samples. 
The values for $\mathrm{Th} / \mathrm{Cr}$ are within the range proposed by Cullers $(1994,2000)$ and Cullers et al. (1988) for felsic rocks. Samples from the São Carlos Formation have similar values to those from the Araçatuba Formation in western Minas Gerais (Mattos, 2014), which may indicate a similar sedimentary contribution in other portions of the basin.

Based on data on major and trace elements and ratios between trace elements, it is possible to define that the São Carlos Formation was sourced mainly from felsic rocks and, to a lesser extent, intermediate rocks and recycled sediments, indicating that these sediments derive mostly from proximal source areas.

\section{DISCUSSION}

\section{Tectonic setting in the eastern edge of the Bauru Basin}

Considering an Upper Santonian depositional age for the São Carlos Formation (Arai and Dias-Brito, 2018), a potential source area for these deposits is the ConiacianMaastrichtian uplifting in the Serra do Mar region (Zalán and Oliveira, 2005), whereas the Cenomanian to Campanian Alto Paranaíba Uplift has been inferred as a probable source for the Araçatuba Formation (Hasui and Haralyi, 1991; Batezelli, 2017; Marques dos Santos et al., 2019).

The Serra do Mar Uplift began at 89.5 - 88 Ma (Zalán and Oliveira, 2005), increasing the sediment supply to the Santos Basin to the east and the Bauru Basin to the west (Menegazzo et al., 2016). The Alto Paranaíba Uplift is a tectonic feature in western Minas Gerais and southern Goiás, which was activated mainly in the Upper Cretaceous and served as a geological boundary separating the Bauru Basin from the Sanfranciscana Basin located in the north (Figures 11A and 11B). This uplift was also marked by magmatic activity that contributed to both basins (Hasui and Haralyi, 1991; Batezelli and Ladeira, 2016). In the Alto Paranaíba region, the Precambrian basement consists of metasedimentary rocks from the Araxá (mica schist, quartzite, and phyllite) and Canastra (quartzite and phyllite) groups and mudstones from the Bambuí Group (Hasui, 1968). Mesozoic uplifting is also associated with intrusions of ultramafic, alkaline, and carbonate bodies occurring throughout the Cretaceous (Gibson et al., 1995; Campos and Dardenne, 1997).

Sedimentary rocks from the Paraná Basin and basalts from the Serra Geral Formation acted as source rocks for the northern and eastern areas of the Bauru Basin by the Maastrichtian-Paleocene (Gravina et al., 2002).

By the time of deposition of the São Carlos Formation, alkaline intrusions occurred in different regions due to the passage of the South American Plate over a hotspot (Gibson et al., 1995). This mantle plume caused uplift in southern Minas Gerais, leading to the exhumation of the Precambrian basement, some Paleozoic sedimentary units from the Serra Geral basalts. Sediment derived from erosion of these geological units were transported to the Bauru Basin by means of a paleodrainage coming from the north and northeast (Batezelli et al., 2007; Batezelli, 2010, 2017; Batezelli and Ladeira, 2016) (Figure 11). By contrast, the interpreted felsic nature of the source rocks from the São Carlos Formation (Table 3) does not fit into this predefined paleogeographic setting.

The map in Figure 11 and the NW-SE sections presented in Figure 11C illustrate the interpreted source rocks and paleogeographic setting for the São Carlos Formation. Based on data from Zalán and Oliveira (2005), Karl et al. (2013), Menegazzo et al. (2016), and the classification of sedimentary provenance obtained in this paper, we can assume that the sediments originated from erosion of the Serra do Mar felsic rocks, which include different types of granites and gneisses (Almeida and Carneiro, 1998). Debris from the Serra do Mar Uplift during the Late Cretaceous supplied the Santos Basin (Figures 11A and 11C), giving rise to the Jureia and Itajaí-Açu Formations (Almeida and Carneiro, 1998), and the continent interior (Bauru Basin). The Serra do Mar thus acted as a tectonically active, eastern border of the Bauru Basin by the time of deposition of the São Carlos

Table 3. $\mathrm{La} / \mathrm{Sc}, \mathrm{Th} / \mathrm{Sc}$, and Th/Cr ratios are correlated with the values of the upper continental crust (UCC) from Rudnick and Gao $(2003)^{\star}$, Post-Archean average Australian shale (PAAS) ${ }^{\star \star}$, Taylor and McLennan (1985), mafic ${ }^{\star \star \star}$ and felsic ${ }^{\star \star \star}$ rocks Cullers $(1994,2000)$ and Cullers et al. (1988), values of the Araçatuba Formation in western Minas Gerais from Mattos (2014) $)^{\star \star \star \star}$, and values of samples from the São Carlos Formation ${ }^{\star \star \star \star \star}$.

\begin{tabular}{|c|c|c|c|}
\hline & $\mathrm{La} / \mathrm{Sc}$ & Th/Sc & $\mathrm{Th} / \mathrm{Cr}$ \\
\hline UCC $^{*}$ & 2.21 & 0.75 & 0.11 \\
\hline PAAS** & 2.37 & 0.75 & 0.13 \\
\hline Variation for mafic rocks ${ }^{\star \star \star}$ & $0.43-0.86$ & $0.05-0.22$ & $0.018-0.046$ \\
\hline Variation for felsic rocks ${ }^{\star \star \star}$ & $2.5-16.3$ & $0.84-20.5$ & $0.13-2.7$ \\
\hline Variation values from Mattos ${ }^{\star \star \star \star}$ & $1.47-4.86$ & $0.1-1.91$ & $0.008-0.14$ \\
\hline Variation values obtained ${ }^{\star \star \star \star \star}$ & $1.87-12.43$ & $0.31-1.95$ & $0.07-0.42$ \\
\hline Mean values $(n=21)$ from Mattos ${ }^{\star \star \star \star}$ & 3.00 & 0.62 & 0.037 \\
\hline Mean values obtained $(n=17)^{\star \star \star \star \star}$ & 8.77 & 1.27 & 0.17 \\
\hline
\end{tabular}


Formation. The $\mathrm{TiO}_{2}$ values present in the samples - intermediate rocks in Figures 10C, 11B, and 11C - show an influence of basalts from the Serra Geral Formation.
The sediments provenance is a mixture of felsic and mafic sediments, with greater felsic influence and sediment recycling. Granites and gneisses derive from the Serra do

A

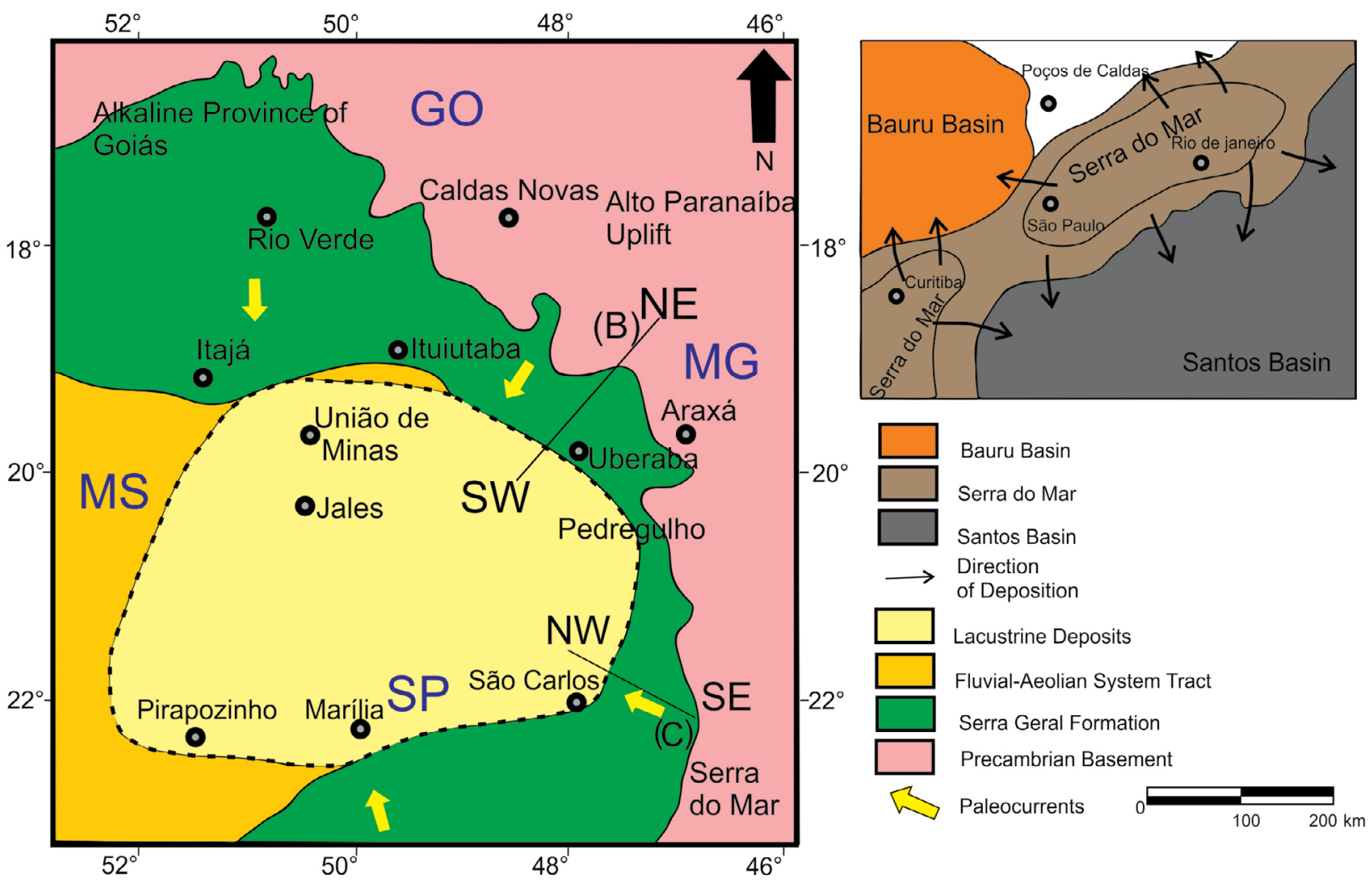

B

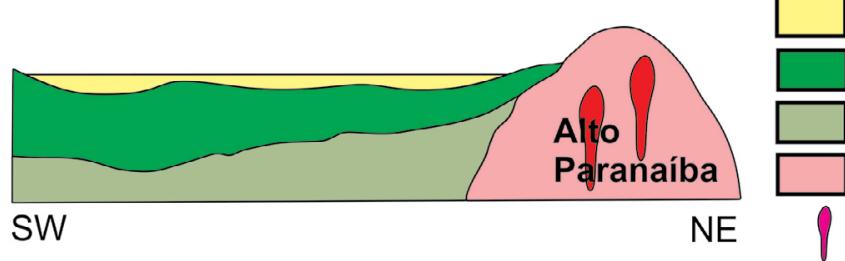

Lacustrine Deposits

Serra Geral Formation

Paleozoic Units of

Bacia do Paraná

Precambrian Basement

SW

Alkaline intrusion

C

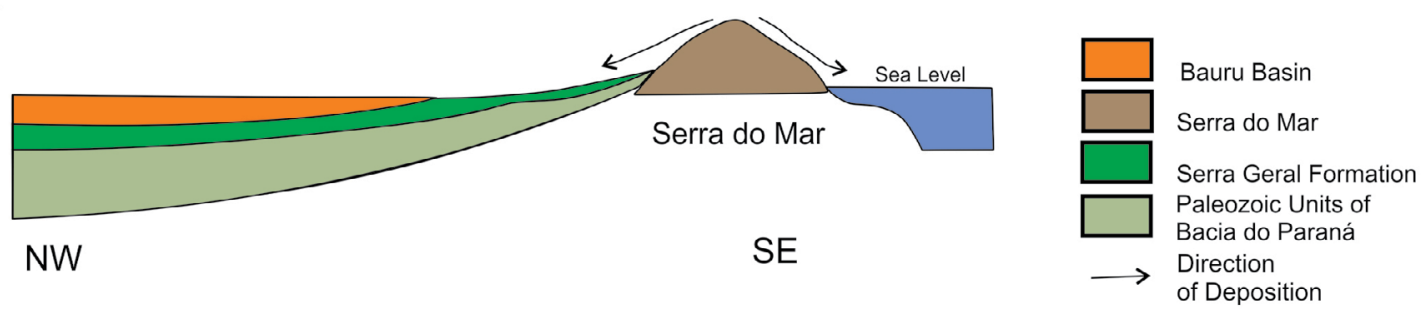

Source: based on Almeida and Carneiro (1998), Batezelli (2017), Karl et al. (2013), and Zalán and Oliveira (2005).

Figure 11. Paleogeography map of the north-eastern edges of the Bauru Basin. (A) Representative model of distribution of the eroded sediments from the Serra do Mar. (B) SW-NE steering profile. (C) NW-SE steering profile indicating the directions of deposition of eroded schematic geological profiles showing the source areas during the Upper Cretaceous. 
Mar Uplift and the basalts from the Serra Geral Formation, present extensively in the basin.

\section{Comparison between the São Carlos and Araçatuba formations}

Comparing the values obtained in this paper with those from the western border of the Bauru Basin (Mattos, 2014; Mattos and Batezelli, 2014), we can conclude that although similar in terms of facies and depositional environments, the source areas for the Araçatuba and São Carlos formations are not the same. While the eastern region of the basin received sediments from both the Serra do Mar and Alto Paranaíba uplifts, sediments in the west were sourced only from the Alto Paranaíba Uplift to the north.

The deposition of lacustrine sediments in the São Carlos Formation started in the Upper Santonian, whereas the Araçatuba Formation is considered as Coniacian, so at least part of these units can be coeval. The main difference is the presence of black shales in the São Carlos Formation, indicating a larger accommodation space and lower sediment input, probably related to more expressive participation of tectonics near the active eastern border of the basin.

Despite these findings, an investigation of the mapping of the São Carlos Formation is necessary to understand its provenance better and compare it with other formations of the Bauru Basin.

\section{CONCLUSIONS}

Based on sedimentological and geochemical data discussed in this paper, we can enumerate the following conclusions regarding the sedimentary provenance of the São Carlos Formation in the context of the eastern Bauru Basin:

I. The analyzed sediments derive mostly from felsic, intermediate, and recycled source rocks;

II. Chemical weathering indices between 57.12 and 71.58 suggest moderate weathering, with higher alteration recorded in lacustrine black shales;

III. Sediments from the São Carlos Formation were sourced mainly from the Serra do Mar Uplift to the east and, to a lesser extent, the Alto Paranaíba Uplift to the north, differing from the lithologically similar Araçatuba Formation, and influenced by the Serra Geral Formation.

IV. Considering the depositional ages for the Araçatuba (Coniacian) and São Carlos (Upper Santonian) formations and the similar lacustrine depositional environment for both units, we can conclude that these formations are at least partially correlated, but represent different paleogeographic domains within the Bauru Basin.

\section{ACKNOWLEDGMENTS}

To FAPESP (São Paulo Research Foundation) - Project 2015/17632-5: Sedimentation and pedogenesis in Cretaceous continental sequences of the Bauru, Sanfranciscana, Parecis, and Neuquén basins - for the financial support and to Carlos Conforti Ferreira Guedes and Fernando Farias Vesely for the suggestions and constructive reviews of this paper.

\section{REFERENCES}

Akarish, A. I. M., El-Gohary, A. M. (2011). Provenance and Source Area Weathering Derived from the Geochemistry of Pre-Cenomanian Sandstones, East Sinai, Egypt. Journal of Applied Sciences, 11(17), 3070-3088. https://doi.org/10.3923/ jas.2011.3070.3088

Albarelli, D. S. N. A., Batezelli, A., Cabral Junior, M. (2015). Paleoambientes e caracterização tecnológica para fins cerâmicos da Formação Araçatuba no vale do Rio Santo Anastácio (Bacia Bauru, SP). Geociências, 34(4), 784-800.

Almeida, F. F. M., Carneiro, C. D. R. C. (1998). Origem e evolução da Serra do Mar. Revista Brasileira de Geociências, 28(2), 135-150.

Amaral, G., Bushee, J., Cordani, U. G., Kawashita, K., Reynolds, J. H. (1967). Potassium-argon ages of alkaline rocks from Southern Brazil. Geochimica et Cosmochimica Acta, 31(2), 117-142. https://doi.org/10.1016/S0016-7037(67)80041-3

Arai, M., Dias-Brito, D. (2018). The Ibaté paleolake in SE Brazil: Record of an exceptional late Santonian palynoflora with multiple significance (chronostratigraphy, paleoecology and paleophytogeography). Cretaceous Research, 84, 264285. https://doi.org/10.1016/j.cretres.2017.11.014

Batezelli, A. (2010). Arcabouço tectono-estratigráfico e evolução das Bacias Caiuá e Bauru no Sudeste Brasileiro. Revista Brasileira de Geociências, 40(2), 265-285. https://doi. org/10.25249/0375-7536.2010402265285

Batezelli, A. (2017). Continental systems tracts of the Brazilian Cretaceous Bauru Basin and their relationship with the tectonic and climatic evolution of South America. Basin Research, 29(S1), 1-25. https://doi.org/10.1111/bre.12128

Batezelli, A., Ladeira, F. S. B. (2016). Stratigraphic framework and evolution of the Cretaceous continental sequences of the Bauru, Sanfranciscana, and Parecis basins, Brazil. Journal of South America Earth Sciences, 65, 1-24. https://doi. org/10.1016/j.jsames.2015.11.005 
Batezelli, A., Ladeira, F. S. B., Nascimento, D. L., Silva, M. L. (2019). Facies and palaeosol analysis in a progradational distributive fluvial system from the Campanian-Maastrichtian Bauru Group, Brazil. Sedimentology, 66(2), 699-735. https:// doi.org/10.1111/sed.12507

Batezelli, A., Saad, A. R., Basilici, G. (2007). Arquitetura deposicional e evolução da sequência aluvial neocretácea da porção setentrional da Bacia Bauru, no sudeste brasileiro. Revista Brasileira de Geociências, 37(1), 163-181.

Batezelli, A., Saad, A. R., Etchebehere, M. L. C., Perinotto, J. A., Fúlfaro, V. J. (2003). Análise Estratigráfica Aplicada à Formação Araçatuba (Grupo Bauru - Ks) No Centro-Oeste do Estado de São Paulo. Revista Geociências, 22(Spe. No.), 5-19.

Batezelli, A., Saad, A. R, Perinotto, J. A., Fúlfaro, V. J. (2006). Análise Estratigráfica Aplicada à Reconstrução Paleogeográfica da Porção Norte e Nordeste da Bacia Bauru (Cretáceo Superior). Revista Brasileira de Geociencias, 23(2), 253-268.

Bhatia, M. R., Crook, K. A. W. (1986). Trace element characteristics of greywackes and tectonic setting discrimination of sedimentary basins. Contribution to Mineralogy and Petrology, 92(2), 181-193. https://doi. org/10.1007/BF00375292

Campos, J. E. G., Dardenne, M. A. (1997). Origem e evolução tectônica da Bacia Sanfranciscana. Revista Brasileira de Geociências, 27(3), 283-294.

Castro, J. C., Dias-Brito, D., Arai, M., Rodrigues, R., Musacchio, E. A. (2002). Formação São Carlos: Uma nova unidade para o Grupo Bauru (Cretáceo Continental no Brasil). VI Simpósio sobre o Cretáceo no Brasil, $2^{\circ}$ Simpósio sobre El Cretácico de América Del Sur, 351-357.

Cullers, R. L. (1994). The chemical signature of source rocks in size fractions of Holocene stream sediment derived from metamorphic rocks in the wet mountains region, Colorado, USA. Chemical Geology, 113(3-4), 327-343. https://doi. org/10.1016/0009-2541(94)90074-4

Cullers, R. L. (2000). The geochemistry of shales, siltstones and sandstones of Pennsylvanian-Permian age, Colorado, USA: implications for provenance and metamorphic studies. Lithos, 51(3), 181-203. https://doi.org/10.1016/S0024-4937(99)00063-8

Cullers, R. L., Basu, A., Suttner, L. (1988). Geochemical signature of provenance in sand-size material in soils and stream sediments near the Tobacco Root batholith, Montana, USA. Chemical Geology, 70(4), 335-348. https://doi. org/10.1016/0009-2541(88)90123-4
Fernandes, L. A. (1998). Estratigrafia e Evolução Geológica da Parte Oriental da Bacia Bauru (Ks, Brasil). Tese (Doutorado). São Paulo: Instituto de Geociências - USP. https://doi.org/10.11606/T.44.1998.tde-16012014-142739

Fernandes, L. A., Coimbra, A. M. (1996). A Bacia Bauru (Cretáceo Superior, Brasil). Anais da Academia Brasileira de Ciências, 68(2), 195-205.

Fragoso, C. E., Weinschutz, L. C., Vega, C. S., Guimarães, G. B., Manzig, P. C., Kellner, A. W. A. (2013). Short note on the pterosaurs from the Caiuá Group (Upper Cretaceous, Bauru Basin), Paraná State, Brazil. International Symposium on Pterosaurs, 71-72. Rio de Janeiro: UFRJ.

Garver, J. I., Royce, P. R., Smick, T. A. (1996). Chromium and nickel in shale of the Taconic foreland: a case study for the provenance of fine-grained sediments with an ultramaficsource. Journal of Sedimentary Research, 66(1), 100-106. https://doi.org/10.1306/ D42682C5-2B26-11D7-8648000102C1865D

Gibson, S. A., Thompson, R. N., Leonardos, O. H., Dickin, A. P., Mitchell, J. G. (1995). The late Cretaceous impact of the Trindade mantle plume: evidence from large volume, mafic, potassic magmatism in SE Brazil. Journal of Petrology, 36(1), 189-229. https://doi.org/10.1093/petrology/36.1.189

Gobbo-Rodrigues, S. R. (2001). Carófitas e Ostrácodes do Grupo Bauru. Dissertação (Mestrado). Rio Claro: Instituto de Geociências e Ciências Exatas, Universidade Estadual Paulista "Júlio de Mesquita Filho".

Godoy, L. H., Sardinha, D. S., Moreno, M. M. T. (2017). Major and trace elements redistribution in weathered calystones from the Corumbataí Formation, Paraná Sedimentary Basin, São Paulo, Brazil. Brazilian Journal of Geology, 47(4), 615632. http://dx.doi.org/10.1590/2317-4889201720170086

Gravina, E. G., Kafino, C. V., Brod, J. A., Boaventura, G. R., Santos, R. V., Guimarães, E. M., Jost, H. (2002). Proveniência de arenitos das formações Uberaba e Marília (Grupo Bauru) e do Garimpo do Bandeira: implicações para a controvérsia sobre a fonte do diamante do triângulo Mineiro. Revista Brasileira de Geociências, 32(4), 545558. https://doi.org/10.25249/0375-7536.2002324545558

Guimarães, G. B., Liccardo, A., Godoy, L. C., Weinschutz, L. C., Manzig, P. C., Vega, C. S., Platti, F. (2012). Ocorrência de Pterossauros no Cretáceo da Bacia do Paraná/Bauru: Implicações para a Geoconservacão, Paleontologia e Estratigrafia. XLVI Congresso Brasileiro de Geologia, 48. Santos: SBG. 
Hasui, Y. (1968). A Formação Uberaba. XXII Congresso Brasileiro de Geologia, 167-179. Belo Horizonte: SBG.

Hasui, Y., Cordani, U. G. (1968). Idades potassio-argoônio de rochas eruptivas mesozóicas do oeste mineiro e sul de Goiás. XXII Congresso Brasileiro de Geologia, 139-143. Belo Horizonte: SBG.

Hasui, Y., Haralyi, N. L. E. (1991). Aspectos lito-estruturais e geofísicos do Soerguimento do Alto Paranaíba. Geociências, 10(1), 57-77.

Hayashi, K. I., Fujisawa, H., Holland, H. D., Ohmoto, H. (1997). Geochemistry of $\sim 1,9$ Ga sedimentary rocks from northeastern Labrador, Canada. Geochimica et Cosmochimica Acta, 61(19), 4115-4137. https://doi. org/10.1016/S0016-7037(97)00214-7

Herron, M. M. (1988). Geochemical Classification of Terrigenous sands and shales from core or log data. Journal of Sedimentary Research, 58(5), 820-829. https://doi. org/10.1306/212F8E77-2B24-11D7-8648000102C1865D

Karl, M., Glasmacher, U. A., Kollenz, S., Franco-Margalhães, A. O. B., Stockli, D. F., Hackspacher, P. C. (2013). Evolution of the South Atlantic passive continental margin in southern Brazil derived from zircon and apatite (U-Th-Sm)/He and fission-track data. Tectonophysycs, 604, 224-244. https:// doi.org/10.1016/j.tecto.2013.06.017

Lima, M. R., Mezzalira, S., Dino, R., Saad, A. R. (1986). Descoberta de microflora em sedimentos do Grupo Bauru, Cretáceo do Estado de São Paulo. Revista do Instituto Geológico, 7(1-2), 5-9. http://dx.doi.org/10.5935/0100-929X.19860001

Machado Junior, D. L. (1992). Idades Rb/Sr do complexo alcalino-carbonático de Catalão II (GO). 29th Brazilian Geology Congress, 91-93. São Paulo.

Marques dos Santos, C. A., Batezelli, A., Nakasuga, W. M., Resende, R. S., Tello Saenz, C. A., Nunes, J. O. R. (2019). Sedimentary provenance of the Marília Formation (Bauru Basin), Southeast Brazil. Geological Journal, 1-17. https:// doi.org/10.1002/gj.3576

Mattos, N. H. S. (2014). Geoquimica e proveniência do Grupo Bauru no Oeste de Minas Gerais. Dissertação (Mestrado). Campinas: Instituto de Geociências - UNICAMP.

Mattos, N. H. S., Batezelli, A. (2014). Proveniência e intemperismo de área-fonte do Grupo Bauru no Oeste do Estado de Minas Gerais (Brasil). Comunicações Geológicas, 101(Spe. 1), 205-208.
McLennan, S. M., Hemming, S., McDaniel, D. K., Hanson, G. N. (1993). Geochemical Approaches to Sedimentation, Provenance and Tectonics. In: M. J. Johnsson, A. Basu (Eds.), Processes Controlling the Composition of Clastic Sediments. Geological Society of America, Special Papers, 284, 21-40. http://dx.doi. org/10.1130/SPE284-p21

Menegazzo, M. C., Catuneanu, O., Chang, H. K. (2016). The South American retroarc foreland system: The development of the Bauru Basin in the back-bulge province. Marine and Petroleum Geology, 73, 131-156. https://doi.org/10.1016/j. marpetgeo.2016.02.027

Mezzalira, S. (1974). Contribuição ao conhecimento da estratigrafia e paleontologia do Arenito Bauru. Boletim do Instituto Geográfico e Geológico, 51. 163 p.

Mishra, M., Sen, S. (2012). Provenance, tectonic setting and source area weathering of mesoproterozoic Kaimur Group, Vindhyan Supergroup, Central India. Geologica Acta, 10(3), 283-293. https://doi.org/10.1344/105.000001759

Moradi, A. V., Sar, A., Akkaya, P. (2016). Geochemistry of the Miocene oil shale (Hançili Formation) in the ÇankiriÇorum Basin, Central Turkey: Implications for Paleoclimate conditions, source-area weathering, provenance and tectonic setting. Sedimentary Geology, 341, 289-303. https://doi. org/10.1016/j.sedgeo.2016.05.002

Nesbitt, H. W., Young, G. M. (1982). Early Proterozoic climates and plate motions inferred from major element chemistry of lutites. Nature, 299, 715-717. http://dx.doi. org/10.1038/299715a0

Nesbitt, H. W., Young, G. M. (1984). Prediction of some weathering trends of plutonic and volcanic rocks based on thermodynamics and kinetic considerations. Geochimica et Cosmochimica Acta, 48(7), 1523-1534. https://doi. org/10.1016/0016-7037(84)90408-3

Paula e Silva, F., Kiang, C. H., Caetano-Chang, M. R. (2005). Estratigrafia de subsuperfície do Grupo Bauru (K) no Estado de São Paulo. Revista Brasileira de Geociências, 35(1), 77-88.

Quintão, D. A., Caxito, F. A., Karfunkel, J., Vieira, F. R., Seer, H. J., Moraes, L. C., Ribeiro, L. C., PedrosaSoares, A. C. (2017). Geochemistry and sedimentary provenance af the Upper Cretaceous Uberaba Formation (Southeastern Triângulo Mineiro, MG, Brazil). Brazilian Journal of Geology, 47(2), 159-182. https://doi. org/10.1590/2317-4889201720170032 
Riccomini, C. (1995). Tectonismo gerador e deformador dos depósitos sedimentares pós-Gondwânicos da porção centro-oriental do Estado de São Paulo e áreas vizinhas. Tese (Livre-Docência). São Paulo: Instituto de Geociências - USP. https://doi.org/10.11606/T.44.2013. tde-03062013-103524

Riccomini, C. (1997). Arcabouço estrutural e aspectos do tectonismo gerador e deformador da Bacia Bauru no Estado de São Paulo. Revista Brasileira de Geociências, 27(2), 153-162. https://doi.org/10.25249/0375-7536. 1997153162

Roser, B., Korsch, R. (1988). Provenance signatures of sandstone-mudstone suites determined using discriminant function analysis of major element data. Chemical Geology, 67(1-2), 119-139. https://doi. org/10.1016/0009-2541(88)90010-1
Roy, D. K., Roser, B. P. (2013). Geochemical evolution of the Tertiary succession of the NW shelf, Bengal Basin, Bangladesh: Implications for provenance, paleoweathering and Himalayan erosion. Journal of Asian Earth Sciences, 78, 248-262. https://doi.org/10.1016/j.jseaes.2013.04.045

Sonoki, I. K., Garda, G. M. (1988). Idades K-Ar de rochas alcalinas do Brasil Meridional e Paraguai Oriental: compilação e adaptação às novas constantes de decaimento. Boletim IG-USP. Série Cientifica, 19, 63-85. https://doi.org/10.11606/ issn.2316-8986.v19i0p63-85

Taylor, S. R., McLennan, S. M. (1985). The Continental Crust: Its Composition and Evolution. Oxford: Blackwell, 312 p.

Zalán, P. V., Oliveira, J. A. B. (2005). Origem e evolução estrutural do Sistema de Riftes Cenozóicos do Sudeste do Brasil. Boletim de Geociências Petrobras, 13(2), 269-300. 


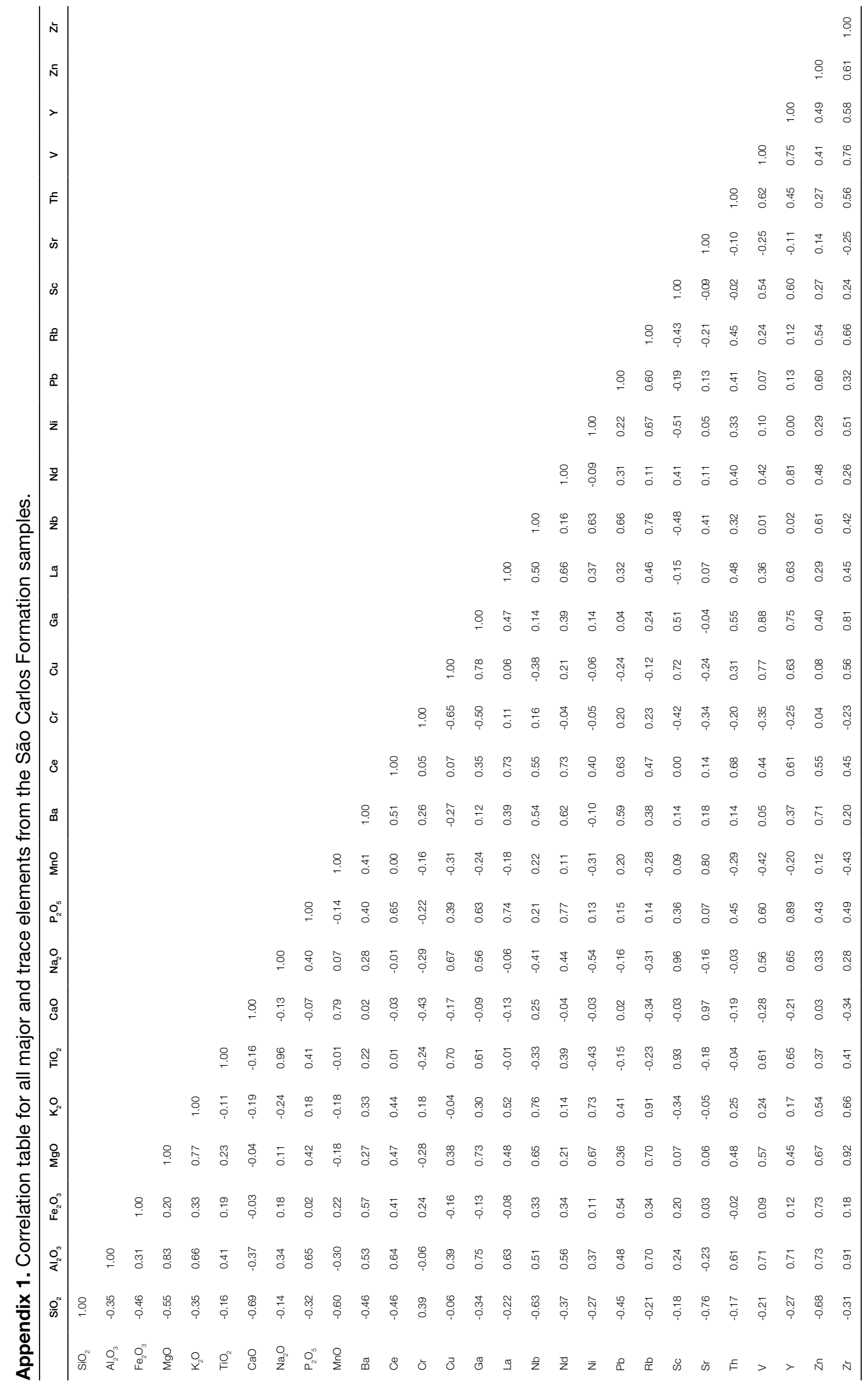

